\title{
Does obesity increase the risk of stroke?
}

\section{Czy otyłość zwiększa ryzyko wystąpienia udaru?}

\author{
Jacek Sajdak ${ }^{1, A-D, F}$, Dominika Stępieńn ${ }^{1, A-D}$, Paulina Werel ${ }^{1, A-D}$, Agata Czarnowska ${ }^{2, A-B, E-F}$, \\ Katarzyna Kapica-Topczewska ${ }^{2, E-F}$, Alina Kułakowska ${ }^{2, E-F}$ \\ ${ }^{1}$ Student Scientific Circle, Clinic of Neurology, Medical University, Bialystok, Poland \\ ${ }^{2}$ Clinic of Neurology, Medical University, Bialystok, Poland \\ A - Koncepcja i projekt badania, B - Gromadzenie i/lub zestawianie danych, C - Analiza i interpretacja danych, \\ D - Napisanie artykułu, E - Krytyczne zrecenzowanie artykułu, F - Zatwierdzenie ostatecznej wersji artykułu
}

Sajdak J, Stępień D, Werel P, Czarnowska A, Kapica-Topczewska, Alina Kułakowska. Does obesity increase the risk of stroke? Med Og Nauk Zdr. 2019; 25(4): 204-207. DOI: 10.26444/monz/114153

\section{Abstract}

Introduction. According to the World Health Organization (WHO), about 15 million people worldwide suffer from stroke each year, which makes it the second leading cause of death and the leading cause of acquired disability in adults. Obesity is considered to be a great risk factor for stroke. It appears to play a role in the functional outcome and mortality. Obesity can be expressed by many indicators. Most commonly used is Body Mass Index (BMI).

Objective. The aim of the study is to determine whether obesity increases the risk of stroke and present the recent state of knowledge about predictors for stroke incidence.

Brief description of the state of knowledge. It seems that BMI cannot be taken into consideration as an isolated risk factor for stroke. BMI limitations create a need for better obesity indicators. Recently, it was highlighted that abdominal obesity and its indicators might be a better predictor for stroke incidence compared to BMI. This seems reasonable if recent studies are taken into account in which it was found that abdominal fat has more metabolic activity than subcutaneous fat.

Conclusions. The use of the alternative obesity measurements, such as waist-to-hip ratio (WHR) and waist-to-height ratio (WHtR), could help to correct limitations linked to the BMI, especially regarding patients with visceral type of obesity. All three obesity markers (BMI, WHR and WHtR) should be considered for use in every day practice.

\section{Key words}

stroke, abdominal obesity, risk factors, body mass index

\section{Streszczenie}

Wprowadzenie. Według Światowej Organizacji Zdrowia każdego roku ok. 15 mln ludzi na całym świecie cierpi z powodu udaru, co czyni go drugą najczęstszą przyczyną śmierci i główną przyczyną nabytej niepełnosprawności u dorosłych. Otyłość jest uważana za istotny czynnik ryzyka udaru mózgu, prawdopodobnie mający również wpływ na rokowanie oraz śmiertelność poudarową. Otyłość można zmierzyć za pomocą wielu wskaźników, przy czym najczęściej stosowanym jest wskaźnik masy ciała (ang. Body Mass Index, BMI).

Cel pracy. Celem pracy jest określenie, czy otyłość zwiększa ryzyko wystąpienia udaru, i przedstawienie aktualnego stanu wiedzy na temat wskaźników ryzyka wystąpienia udaru.

Opis stanu wiedzy. Wydaje się, że BMI nie może być brane pod uwagę jako izolowany czynnik ryzyka udaru. Ograniczenia związane ze stosowaniem BMI stwarzają potrzebę poszukiwania lepszych wskaźników otyłości. W ostatnich latach podkreśla się, że otyłość brzuszna i jej markery mogą stanowić bardziej wiarygodne wskaźniki ryzyka udaru mózgu w porównaniu do BMI. Uzasadniają to ostatnie badania, w których stwierdzono, że tłuszcz brzuszny ma większą aktywność metaboliczną niż podskórna tkanka tłuszczowa.

Podsumowanie. Zastosowanie innych wskaźników otyłości, takich jak stosunek obwodu talii do obwodu bioder (ang. waist-to-hip ratio, WHR) oraz stosunek obwodu talii do wzrostu (ang. waist-to-height ratio, WHtR), może pomóc w skorygowaniu ograniczeń BMI, szczególnie w przypadku pacjentów z otyłością brzuszną. Wydaje się, że w celu najdokładniejszego określenia ryzyka, jakie niesie otyłość w udarze niedokrwiennym mózgu, wszystkie trzy markery (BMI, WHR, WHtR) powinny być stosowane jednocześnie w codziennej praktyce.

\section{Słowa kluczowe}

udar, otyłość brzuszna, czynniki ryzyka, wskaźnik masy ciała

\section{INTRODUCTION}

According to the World Health Organization (WHO), about 15 million people worldwide suffer from stroke each year, which makes it the second leading cause of death and the

Address for correspondence: J. Sajdak, Student Scientific Circle, Clinic of Neurology, Medical University, Bialystok, Poland

E-mail: jcksajdak@gmail.com

Received: 06.02.2019; accepted: 12.11.2019; first published: 17.12.2019 leading cause of acquired disability in adults. Although treatment therapies are developing dynamically, prevention is still considered the most effective way to improve the current epidemiological situation. Unmodifiable risk factors for stroke are gender, age, ethnic origin and family history of stroke. There are also many modifiable risk factors which could be reduced, such as hypertension, diabetes mellitus, cardiac diseases, hyperlipidaemia, current smoking, improper diet, low physical activity and alcohol intake. 
Among others, obesity is considered to be a great risk factor for stroke. It appears to play a role in the functional outcome and mortality, and can be expressed by many indicators. Most commonly used is Body Mass Index (BMI). Recently, it was highlighted that abdominal obesity and its indicators might be a better predictor for stroke incidence compared to BMI. Abdominal obesity is also thought to correlate with stroke outcome.

BMI and stroke. BMI [Body Mass Index] is the most commonly used indicator of adiposity worldwide. The great advantage is that it is easily measured and quickly obtained. The calculation requires the patient's height and weight:

$$
\mathrm{BMI}=\text { weight }[\mathrm{kg}] / \text { height }^{2}\left[\mathrm{~m}^{2}\right] \text {. }
$$

The WHO classified particular ranges of BMI as indicators of under-, normal-, overweight and obesity, respectively:

$$
\begin{gathered}
\mathrm{BMI}<18.5 \mathrm{~kg} / \mathrm{m}^{2}-\text { underweight } \\
\mathrm{BMI}=18.5-24.99 \mathrm{~kg} / \mathrm{m}^{2}-\text { normal weight } \\
\mathrm{BMI}=25-29.99 \mathrm{~kg} / \mathrm{m}^{2}-\text { overweight } \\
\mathrm{BMI}>30 \mathrm{~kg} / \mathrm{m}^{2}-\text { obesity. }
\end{gathered}
$$

Obesity is responsible for increasing the risk of chronic diseases, such as cardiovascular diseases (CVDs), and became an increasing worldwide problem due to improper diet and lack of physical activity. It is estimated that in all high-income and most middle-income countries overweight kills more people than underweight [1].

As ischemic stroke has become one of the most common causes of disability and mortality, many studies were conducted to evaluate the value of BMI as an independent risk factor for ischemic stroke. There is a significant correlation between obesity and other risk factors for ischemic stroke, such as high blood pressure, hyperglyacemia and hypercholesterolaemia [2].

The prospective cohort study performed on 116,759 women in the United States (US) indicated that not only obesity, but also weight gain are important risk factors for stroke [3]. Kurth et al. [4, 5] published two large prospective cohort studies on 21,414 US males and 39,053 US females. After 12.5-year and 16-year follow up, both studies showed that both men and women with a BMI of $>30 \mathrm{~kg} / \mathrm{m}^{2}$ had higher risk for stroke, compared to the non-obese population. BMI was also proven to be a significant risk factor for ischemic stroke, not only in Europe and Northern America, but also in Asian population [6].

However, BMI as a stroke risk predictor has its limitations. A prospective population-based study published in 2018 by Zahn et al. [7] showed that BMI is not associated with the incidence of ischemic stroke. A similar result was obtained by Seung-Han Suk et al. [8], in which BMI was not significantly associated with ischemic stroke incidence.

Another interesting aspect is the association between obesity and severity, mortality, and recurrence of stroke and functional outcome after stroke. Ovbiagele et al. assessed data from 20,246 subjects classified by their BMI measurements and waist circumference. The authors found no statistically significant difference in the recurrence of ischemic stroke for several populations over a 2.5-year follow-up. A secondary outcome, however, was paradoxical: being obese was as a protective factor compared with the lean group [9]. Furthermore, a study by Andersen KK and Olsen TS has shown that the risk of recurrent stroke was significantly lower in obese than in normal weight patients. This phenomenon was called 'the obesity paradox' [10].

In contrast, in some studies higher BMI was found to be a predictive indicator for poor stroke outcome in both genders, and there was no significant association with hospital mortality. Dehlendorff, Andersen and Olsen undermined the theory of obesity paradox in stroke. In their study assessing survival after stroke in 71,617 patients, BMI was inversely related to the mean age of stroke onset: stroke occurred in significantly younger patients with higher BMI levels. There was no difference in the risk of stroke mortality in the first month of the study among normal weight, overweight and obese patients [11].

Undoubtedly, BMI as an obesity measurement has its merits. It is easy to obtain, simple to calculate and already well-rooted in the patient's own health awareness. However, it is not the ideal obesity measurement to use. There is no distinction between fat and muscles in the BMI formula, which can result in the paradoxical situation where an athlete has a higher BMI than a significantly obese person. Second, BMI can be an improper obesity indicator for the elderly. Lean body mass declines with age while fat body mass can increase, which may result in no measurable changes in BMI. Also, BMI does not offer any discrimination between genders, although it is commonly known that males and females are prone to be affected by different types of obesity. All these flaws may additionally lead to an 'obesity paradox in stroke' phenomenon, meaning that overweight patients have a lower risk of stroke in general, lower risk of recurrent severe stroke, and better functional outcomes in rehabilitation.

The 'obesity paradox' remains a controversial matter as overweight patients affected by stroke may have a better rehabilitation result, but have their first stroke at a significantly younger age. However, considering that treatment and rehabilitation are long-term, exhausting processes, it still may be true that an elevated BMI is a protective factor - an overweight person has enough body mass to lose during the process without any unfavorable effects on general health [12]. On the other hand, some positive relationship between leptin concentration and sepsis survivors was observed which can suggest its protective value in critical states [13]. Studies that prove the existence of the discussed phenomenon may have been performed without using the best possible and the most credible statistical methods, resulting in an index event bias.

It seems that BMI cannot be taken into consideration as an isolated risk factor for stroke, but it can be useful in combination with other risk factors. All of BMI limitations create a need for the search for better obesity indicators.

Abdominal adiposity indicators and stroke. Abdominal obesity (also known as android, visceral, central adiposity or male-type obesity) is one of the main risk factors for cerebrovascular diseases. The most popular abdominal adiposity indicators are waist-to-hip ratio (WHR), waistto-height ratio (WHtR) and waist circumference (WC). Although they are still less widely used in clinical practice than BMI, recent studies have shown that they are more accurate indicators for stroke risk. 
WHR is calculated as waist measurement divided by hip measurement. The waist circumference is measured with a flexible tape at the midpoint between the lower margin of the last palpable ribs and the top of the iliac crest; hip circumference should be measured around the widest portion of the buttocks, with the tape parallel to the floor. Elevated WHR value is defined as higher than 0.92 in men and 0.82 in women. WHtR is an abdominal adiposity indicator obtained by dividing waist circumference by height. Global cut-off value of WHtR is 0.5 , and is the same for men and women because the average man are taller than the average woman, and their WCs are wider. WC is measured at a level midway between the lowest rib and the iliac crest. The WC of $\geq 102 \mathrm{~cm}$ for men and $\geq 88 \mathrm{~cm}$ for women is related with increased cardiometabolic risk, and therefore considered as cut-off points. The MORGAM Study from 2011 highlighted the importance of measuring WC among patients. 31201 men and 23516 women were included in the study with an 11-year follow up. At the endpoint of the study 720 strokes occurred in men and 410 in women. It was observed that increased WHR and WHtR were associated with higher stroke risk [WHR: $\mathrm{RR}=1.14$ in men, $\mathrm{RR}=1.08$ in women, WHtR: $R R=1.5$ in men, $R R=1.31$ in women] [2]. Based on literature it appears that measurements of WHtR and WHR can potentially improve the stroke risk assessment. According to MORGAM (MOica Risk, Genetics, Archiving and Monograph Proct), WHtR is a better predictor compared to WHR in stroke risk assessment, although WHtR is still less commonly used. Stroke risk among women was lower than in men. However, a surprising study was published in the Journal of the American Medical Association (JAMA) in which the role of WHR among women as a stroke predictor was undermined. In this prospective cohort study with a 19.5-year follow-up, 3,228 patients developed an incident of a stroke event [2,554 ischemic and 674 haemorrhagic strokes]. After statistical analyses, the correlation between WHR and ischemic stroke was observed in men, but not in women. In the group of patients with haemorrhagic stroke, no significant correlations between stroke and WHR were found in either gender [14]. This restricts the usefulness of WHR only to the group of men with ischemic stroke. It should be noted that this study had some limitations resulting from measurement errors which may occur especially during measurement of patients who are unable to stand and the measurements were taken in the supine position. Studies showed that WC measured in this position was slightly smaller compared to measurements performed in the standing position. Furthermore, despite the large number of individuals included in the study, the group of patients was very homogeneous, which may lead to the wrong conclusions.

It is worth mentioning that some studies with less numerous populations indicate a relationship between WHR and risk for stroke also among women. For instance, the Northern Manhattan Stroke Study performed on 576 patients with first ever ischemic stroke, showed that men with a WHR of $\geq 0.93$ had a greater risk of ischemic stroke than women with a WHR of $\geq 0.86$ [8]. Interestingly, according to the authors, this gender difference was not solely a result of a bigger quantity of abdominal fat in men, but also its quality. There are reports suggesting increased metabolic activity in male abdominal fat, which makes it more dangerous than female abdominal fat. It is interesting to note that the risk of ischemic stroke was higher especially among younger persons (odds ratio 4.4 in group $<65$ years vs. 2.2 in the group $\geq 65$ ] [8]. This would indicate that stroke prevention campaigns should also be targeted at younger patients.

Recently, few studies have evaluated the relationship between abdominal obesity indicators and outcome or mortality after ischemic stroke. Ping Yu et al. [15] have shown that excessive abdominal fat accumulation, expressed by WHtR, is associated with worse functional outcome. The correlation with mortality was only significant in younger male patients - under 65-years-old.

There are reports comparing obesity indicators such as BMI, WHR, WC and WHtR, which attempt to determine the superiority of one over the others. The PREMIER study, similar to the study by Ping Yu et al., not only indicated a relationship between high WHtR [over 0.70] and increased chances of severe disability after ischemic stroke, but also showed WHtR as a better predictor of body fat than BMI [16]. Kyusik Kang et al. confirmed the existence of the 'obesity paradox' only in men for both- BMI and WHR, with a slight advantage of WHR. On the other hand, results presented by Bembenek et al. suggest that being overweight measured by WC is a strong predictor of good outcome, but surprisingly only in the female group, which makes WC gender-specific [17]. On the contrary, in this study high WHR predicted poor ischemic stroke outcome in both genders and BMI had the least clinical value in predicting ischemic stroke outcome.

In summary, WHtR and WHR are being considered as alternative predictors for ischemic stroke risk and functional outcome after ischemic stroke. This seems reasonable if one takes into account recent studies which found that abdominal fat has more metabolic activity than subcutaneous fat. Visceral fat is considered by some as a separate endocrine organ with its own high production of free fatty acids and cytokines which support inflammatory reactions and triggers endothelial injury and hypertension leading to stroke. Taking into consideration the fact that stroke is more common in patients with visceral adiposity than general adiposity - abdominal adiposity indicators may have an advantage over BMI in predicting the risk of stroke. This has been highlighted in the INTERSTROKE study, the first large standardized case-control study performed in 22 countries worldwide between March 2007 - April 2010. The study showed a stronger association of stroke risk with WHR than with BMI [18]. However, as shown above, the results in some studies were not so unequivocal as those in the INTERSTROKE study. Further studies, particularly prospective cohort studies carried out on large, diverse populations, must be undertaken in the future to confirm the correlation between WHR and stroke risk, especially among women.

\section{CONCLUSIONS}

$\mathrm{BMI}$ is the most common measurement of obesity. However, this measurement is not as precise as it should be and cannot be considered as a stroke risk predictor alone.

The use of the alternative obesity measurements, such as WHR and WHtR, could assist in correcting limitations linked to the BMI, especially regarding patients with visceral type of obesity which is strongly related with stroke. WHR and WHtR not only better reflect the visceral obesity, but they also take into consideration the differences between genders. There are different norms of normal WHR and 
WHtR values for men and women. It is also worth bearing in mind that the lean body mass declines with age, and the fat content, which is most likely responsible for heightening the risk for stroke, does not change or increase. In such situation, WHtR and WHR would be much more sensible for indicating changes than BMI.

For these reasons, all three obesity markers - BMI, WHR and WHtR - should be considered for use in everyday practice.

\section{REFERENCES}

1.WHO. Global health risks: mortality and burden of disease attributable to selected major risks. Geneva: World Health Organization;2009.

2. Bodenant M, Kuulasmaa K, Wagner A, et al. Measures of abdominal adiposity and the risk of stroke: the MOnica Risk, Genetics, Archiving and Monograph (MORGAM) study. Stroke. 2011; 42(10): 2872-2877.

3. Rexrode KM, Hennekens $\mathrm{CH}$, Willett WC, et al. A prospective study of body mass index, weight change, and risk of stroke in women. Jama 1997; 277(19): 1539-1545.

4. Kurth T, Gaziano JM, Berger K, et al. Body mass index and the risk of stroke in men. Arch Intern Med. 2002; 162(22): 2557-2562.

5. Kurth T, Gaziano JM, Rexrode KM, et al. Prospective study of body mass index and risk of stroke in apparently healthy women. Circulation. 2005; 111(15): 1992-1998.

6. Chen Z, Iona A, Parish S, et al. Adiposity and risk of ischaemic and haemorrhagic stroke in 0.5 million Chinese men and women: a prospective cohort study. Lancet Glob Health. 2018; 6(6): e630-e640.

7.Zahn K, Linseisen J, Heier M, et al. Body fat distribution and risk of incident ischemic stroke in men and women aged 50 to 74 years from the general population. The KORA Augsburg cohort study. PLoS One. 2018; 13(2): e0191630.

8. Suk SH, Sacco RL, Boden-Albala B, et al. Abdominal obesity and risk of ischemic stroke: the Northern Manhattan Stroke Study. Stroke. 2003; 34(7): 1586-1592.

9. Ovbiagele B, Bath PM, Cotton D, et al. Obesity and recurrent vascular risk after a recent ischemic stroke. Stroke. 2011; 42(12): 3397-3402.

10. Andersen KK, Olsen TS. The obesity paradox in stroke: lower mortality and lower risk of readmission for recurrent stroke in obese stroke patients. Int J Stroke. 2015; 10(1): 99-104.

11. Dehlendorff C, Andersen KK, Olsen TS. Body mass index and death by stroke: no obesity paradox. JAMA Neurol. 2014; 71(8): 978-984.

12. Katsnelson M, Rundek T. Obesity paradox and stroke: noticing the (fat) man behind the curtain. Stroke. Vol 42. United States. 2011: 3331-3332.

13. Bornstein SR, Licinio J, Tauchnitz R, et al. Plasma leptin levels are increased in survivors of acute sepsis: associated loss of diurnal rhythm, in cortisol and leptin secretion. J Clin Endocrinol Metab. 1998; 83(1): $280-283$.

14. Hu G, Tuomilehto J, Silventoinen K, et al. Body mass index, waist circumference, and waist-hip ratio on the risk of total and type-specific stroke. Arch Intern Med. 2007; 167(13): 1420-1427.

15. Yu P, Pan Y, Zheng H, et al. Association of high waist-to-height ratio with functional outcomes in patients with acute ischemic stroke: A report from the ACROSS-China study. Medicine (Baltimore). 2017; 96(13): e6520.

16. Chiquete E, Cantu-Brito C, Villarreal-Careaga J, et al. Obesity paradox and functional recovery in first-ever acute ischemic stroke survivors: the PREMIER study. Rev Neurol. 2010; 51(12): 705-713.

17. Bembenek JP, Karlinski M, Niewada M, et al. Measurement of Nutritional Status Using Body Mass Index, Waist-to-Hip Ratio, and Waist Circumference to Predict Treatment Outcome in Females and Males with Acute First-Ever Ischemic Stroke. J Stroke Cerebrovasc Dis. 2018; 27(1): 132-139.

18. O'Donnell MJ, Xavier D, Liu L, et al. Risk factors for ischaemic and intracerebral haemorrhagic stroke in 22 countries (the INTERSTROKE study): a case-control study. Lancet 2010; 376(9735): 112-123. 